\title{
IDENTIFICATIONS OF CARCASS CHARACTERISTIC FOR ESTIMATING THE COMPOSITION OF BEEF CARCASS
}

\author{
H. Hafid ${ }^{1}$., R.E. Gurnadi ${ }^{2}$, R. Priyanto ${ }^{2}$ and A. Saefuddin ${ }^{3}$ \\ ${ }^{1}$ Department of Animal Husbandry, Faculty of Agriculture, \\ Haluoleo University, Kendari 93232 - Indonesi \\ ${ }^{2}$ Department of Animal Production, Faculty of Animal Science, \\ Bogor Agricultural Universit, Jl. Agatis-Darmaga Campus, Bogor 16680 - Indonesia \\ ${ }^{3}$ Department of Statistics, Faculty of Sciences, \\ Bogor Agricultural Universit, Darmaga Campus, Bogor 16680 - Indonesia \\ Corresponding E-mail: harapinhafid@yahoo.co.id
}

Received Novemver 17, 2009; Accepted February 23, 2010

\begin{abstract}
The research aimed to identify carcass characteristic that can be used for estimating composition of beef carcass. It was used 165 Brahman crossbred cattle in this research. Carcass characteristics were weight of a half cold carcass (WC) ranged from 96 to $151 \mathrm{~kg}$, loin eye area (LEA) ranged from 22.09 to $304.8 \mathrm{~mm}^{2}, 12^{\text {th }}$ rib fat thickness (FT12) ranged from 0.80 to $2.90 \mathrm{~mm}$, meat ranged from 53.55 to 90.10 $\mathrm{kg}$ and carcass fat ranged from 5.54 to $39.72 \mathrm{~kg}$. Result showed that a half weight cold carcass as a single indicator major may be used to predict meat weight and carcass fat with regression linear equation: Meat $(\mathrm{kg})=10.64+0.49 \mathrm{WC}\left(\mathrm{R}^{2}=0.728\right.$ and $\left.\mathrm{SE}=3.58\right)$, and Fat $(\mathrm{kg})=-21.70+0.36 \mathrm{WC}^{* *}$ $\left(\mathrm{R}^{2}=0.582\right.$ and $\left.\mathrm{SE}=3.65\right)$. Multiple regression to predict meat weight based on fat percentage of kidney, pelvic and heart $(\mathrm{KPH})$ was Meat $(\mathrm{kg})=7.99+0.58 \mathrm{WC}^{* *}-4.41 \mathrm{KPH}^{* *}\left(\mathrm{R}^{2}=0.751\right.$ and $\left.\mathrm{SE}=3.43\right)$.

Keywords: beef cattle, carcass characteristic, estimation.
\end{abstract}

\section{INTRODUCTION}

One of problems which high attention from people in area of meat industry is no finding in such a way for predicting carcass composition with high accuracy and without much fund. Failure for estimating carcass composition mainly on meat content in carcass can cause bias of "under estimate" and "over estimate". Under estimate can lose out cattle producer (cattle feeder/fattener) and advantage consumer (butcher and retailer), while over estimate has a contrast characteristic, which is disadvantage consumer and advantage producer. It should motivate situation for developing meat industry, ideally, the consumer should pay for cattle prize appropriate with meat content of the carcass.

Murphey et al. (1960) stated that there is a correlation between measurement of sub-cutan fat thick on the $12^{\text {th }}$ rib and meat on beef carcass. This is followed by amount of research showing the correlation between fat thickness on the $10^{\text {th }}$ rib or the $12^{\text {th }}$ rib towards content of carcass fat (Ramsay et al. 1962; Brungardt and Bray 1963; Butterfield 1965; Charles 1974; Priyanto et al,
1997).

Researcher attention for identifying and evaluating other position of beef carcass in which measurement of carcass fat thick as well as other carcass characteristic is possible used for estimating carcass composition (Johnson dan Vidyadaran 1981; Meehan dan Taylor 1988). Their studies concluded that many position of beef carcass in which measurement of fat thick can be conducted and given accurately carcass fat prediction.

Johnson and Ball (1988), and Ball and Johnson (1989) found that there was a correlation between fat thick on the $12^{\text {th }}$ rib or rump position P8 and carcass production from a few various cattle. Hopkins et al. (1993) reported that effect of a relationship cattle species among measurement of fat thick using the $12^{\text {th }}$ rib and rump P8.

This research was carried out to determine a relationship between a variety of carcass characteristic, such as a half carcass weight, loin eye area, fat thick on the $12^{\text {th }}$ rib and percentage of kidney fat, pelvic and heart in line with their combination to carcass composition, especially towards content of meat and beef carcass fat from 
Australian Commercial Crossbred. Those cattle were imported from Australia and used as feeder cattle for feedlot industry in Indonesia.

\section{MATERIALS AND METHOD}

The research was conducted in PT. Celmor Perdana Indonesia which operated Slaughtering House and Laboratory of Large Ruminant, Faculty of Animal Husbandry, Bogor Agricultural University-Bogor.

It was used 165 beef carcass of Crossbred Brahman Cattle (CBC) with feedlot fattening. The used cattle have slaughtered weight $434.03 \pm$ $40.70 \mathrm{~kg}$, with average age based on permanent teeth $\mathrm{I}_{1}-\mathrm{I}_{4}$. Cattle was slaughtered with Halal and acknowledged standardized procedure.

The skin was carefully taken out, especially on position of fat thick measurement was conducted. The measurement procedure was applied following guidelines of Taylor et al (1992). Recording for weight of meat, bone, and fat was carried out on carcass after storage for 24 hours in chilling room.

Analysis of simple linear regression and double regression (Gomez dan Gomez, 1984), was applied for predicting meat component and carcass fat. The weight of a half cold carcass (WC), loin eye area (LEA), fat thickness on the $12^{\text {th }}$ rib (FT12) and fat percentage of kidney, pelvic and heart (KPH) with their combination used as fixed variable. The mathematical model used is:

$Y_{i j}=a+B X_{i j}+\varepsilon_{i j}$

$Y_{i j}=a+B_{4} X_{1}+B_{2} X_{2}+B_{3} X_{3}+B_{4} X_{4}+\varepsilon_{i j}$

where

$Y_{i j}=$ Weight or percentage of carcass component or commercial cutting
$A_{0} \quad=$ Intercept

$B, B_{1}, B_{2}, B_{3}, B_{4}=$ Regression coefficient of variable

$Y_{i}$ towards $X_{i}$

$X_{1}=$ Weight a half cold carcass

$X_{2}=$ Loin eye area

$X_{3}=$ Fat thickness on the $12^{\text {th }}$ rib

$X_{4}=$ Fat percentage of kidney, pelvic and heart

$\varepsilon_{i j}=$ Error

\section{RESULTS AND DISCUSSION}

Carcass characteristic of Crossbred Brahman Cattle is presented in Table 1. Table 1 showed a representation of carcass characteristics (weight of a half cold carcass, loin eye area, fat thickness on the $12^{\text {th }}$ rib, fat percentage of kidney, pelvic and heart, total weight of meat and total weight of carcass fat.

Determining alternative position of carcass characteristic as indicator for meat judging (cutability yield grade) was used WC, measurements of LEA, FT12 and percentage of $\mathrm{KPH}$. The measurement of WC, width of LEA, FT12 and percentage of KPH can be shown in the Table 2 and Table 3.

Analysis of simple regression indicated that $\mathrm{WC}$ as single indicator (independent variable) was highly significant $(\mathrm{P}<0.01)$ related to meat weight with the accuracy level of $\mathrm{R}=72.8 \%$ and $\mathrm{SE}=3.58$. Estimating fat showed highly significant with accuracy level of $\mathrm{R}=58.2 \%$ and SE 3.65.

The result indicated that weight of a half cold carcass as single indicator was dominant in predicting carcass content. It means that the more carcass weight, the more expected meat weight.

Table 1. Carcass Characteristic of Brahman Crossbred

\begin{tabular}{lccccc}
\hline \multicolumn{1}{c}{ Carcass Characteristics } & Sample & Average & SD & Min & Max \\
\hline Weight of a half cold carcass $(\mathrm{kg})$ & 165 & 124.78 & 11.8 & 96 & 151 \\
Loin eye area $\left(\mathrm{mm}^{2}\right)$ & 165 & 262.89 & 24.89 & 22.09 & 304.8 \\
Fat thickness on the $12^{\text {th }}$ rib $(\mathrm{mm})$ & 165 & 1.97 & 0.49 & 0.8 & 2.9 \\
Fat of Kidney, pelvic, and heart $(\%)$ & 165 & 2.98 & 0.6 & 0.89 & 2.9 \\
Meat $(\mathrm{kg})$ & 165 & 72.33 & 6.84 & 53.55 & 90.1 \\
Fat $(\mathrm{kg})$ & 165 & 23.65 & 5.62 & 5.54 & 39.72 \\
\hline
\end{tabular}


Table 2. Correlation between Carcass Characteristics and Meat Weight

\begin{tabular}{|c|c|c|c|c|c|c|c|}
\hline \multirow{2}{*}{$\begin{array}{l}\text { Dependent } \\
\text { variable }\end{array}$} & \multicolumn{5}{|c|}{ Carcass Characteristics (Independent variable) } & \multirow{2}{*}{$\mathrm{R}^{2}$} & \multirow{2}{*}{$\mathrm{SE}$} \\
\hline & Intercept & $\begin{array}{l}\text { WC } \\
(\mathrm{kg})\end{array}$ & $\begin{array}{c}\text { LEA } \\
\left(\mathrm{mm}^{2}\right)\end{array}$ & $\begin{array}{l}\text { FT12 } \\
(\mathrm{mm})\end{array}$ & $\begin{array}{c}\mathrm{KPH} \\
(\%)\end{array}$ & & \\
\hline \multirow[t]{15}{*}{ Meat (kg) } & 10.64 & $0.49 * *$ & & & & 0.73 & 3.58 \\
\hline & 9.98 & $0.49 * *$ & $0.01 \mathrm{~ns}$ & & & 0.73 & 3.59 \\
\hline & 6.83 & $0.53 * *$ & $0.02 \mathrm{~ns}$ & $-1.23 \mathrm{~ns}$ & & 0.73 & 3.59 \\
\hline & 10.73 & $0.51 * *$ & $0.03 \mathrm{~ns}$ & $1.22 \mathrm{~ns}$ & $-2.29 * *$ & 0.75 & 3.47 \\
\hline & 40.78 & & $0.30 * *$ & & & 0.19 & 6.17 \\
\hline & 45.01 & & $0.10^{*}$ & $8.51 * *$ & & 0.48 & 4.96 \\
\hline & 48.59 & & $0.11 *$ & $11.59 * *$ & $-3.44 * *$ & 0.52 & 4.76 \\
\hline & 53.69 & & & $9.47 * *$ & & 0.46 & 5.02 \\
\hline & 55.72 & & & $10.85 * *$ & $-2.72 \mathrm{~ns}$ & 0.47 & 5 \\
\hline & 55.21 & & & & $9.82 * *$ & 0.22 & 6.07 \\
\hline & 9.89 & $0.55 * *$ & & $0.95 \mathrm{~ns}$ & $-4.94 * *$ & 0.75 & 3.44 \\
\hline & 6.45 & $0.57 * *$ & $0.03 \mathrm{~ns}$ & & $-4.53 * *$ & 0.75 & 3.44 \\
\hline & 7.99 & $0.58 * *$ & & & $-4.41 * *$ & 0.75 & 3.43 \\
\hline & 38.51 & & $0.20 * *$ & & $7.26 * *$ & 0.29 & 5.8 \\
\hline & 7.92 & $0.53 * *$ & & $-1.16 \mathrm{~ns}$ & & 0.73 & 3.57 \\
\hline
\end{tabular}

*significant $(p<0.05), \quad * *$ hightly significant $(p<0.01), \quad$ ns: not significant, SE: standard error

Table 3. Correlation between Carcass Characteristics and Fat Weight

\begin{tabular}{|c|c|c|c|c|c|c|c|}
\hline \multirow{2}{*}{$\begin{array}{l}\text { Dependent } \\
\text { Variable }\end{array}$} & \multicolumn{5}{|c|}{ Carcass characteristics (Independent variable) } & \multirow[t]{2}{*}{$\mathrm{R}^{2}$} & \multirow[t]{2}{*}{$\mathrm{SE}$} \\
\hline & Intercept & $\begin{array}{l}\text { WC } \\
(\mathrm{kg})\end{array}$ & $\begin{array}{c}\text { LEA } \\
\left(\mathrm{mm}^{2}\right)\end{array}$ & $\begin{array}{l}\text { FT12 } \\
(\mathrm{mm})\end{array}$ & $\begin{array}{c}\mathrm{KPH} \\
(\%)\end{array}$ & & \\
\hline \multirow[t]{15}{*}{ Fat (kg) } & -21.7 & $0.36^{* *}$ & & & & 0.58 & 3.65 \\
\hline & -21.1 & $0.37 * *$ & $-0.01 \mathrm{~ns}$ & & & 0.58 & 3.66 \\
\hline & -19.08 & $0.34 * *$ & $-0.01 \mathrm{~ns}$ & $0.79 \mathrm{~ns}$ & & 0.58 & 3.66 \\
\hline & -20.61 & $0.35^{* *}$ & $-0.02 \mathrm{~ns}$ & $-0.18 \mathrm{~ns}$ & $0.90 \mathrm{~ns}$ & 0.59 & 3.66 \\
\hline & 2.07 & & $0.20 * *$ & & & 0.13 & 5.26 \\
\hline & 5.6 & & $0.04 \mathrm{~ns}$ & $7.08 * *$ & & 0.43 & 4.27 \\
\hline & 5.48 & & $0.04 \mathrm{~ns}$ & $6.98^{* *}$ & $0.12 \mathrm{~ns}$ & 0.43 & 4.29 \\
\hline & 8.97 & & & $7.46^{* *}$ & & 0.43 & 4.27 \\
\hline & 6.48 & & & $5.76^{* *}$ & $3.33^{*}$ & 0.44 & 4.23 \\
\hline & 6.22 & & & & $10.00^{* *}$ & 0.34 & 4.6 \\
\hline & -20.79 & $0.33 * *$ & & $-0.13 n s$ & $2.01 \mathrm{~ns}$ & 0.59 & 3.64 \\
\hline & -19.52 & $0.33 * *$ & $-0.02 \mathrm{~ns}$ & & $2.02 \mathrm{~ns}$ & 0.59 & 3.64 \\
\hline & -20.53 & $0.33 * *$ & & & $1.94 \mathrm{~ns}$ & 0.59 & 3.63 \\
\hline & -0.72 & & $0.08^{*}$ & & $8.94 * *$ & 0.35 & 4.55 \\
\hline & -19.99 & $0.34 * *$ & & $0.73 \mathrm{~ns}$ & & 0.58 & 3.65 \\
\hline
\end{tabular}

* significant $(P<0.05, \quad * *$ hightly significant $(P<0.01), \quad$ ns: not significant, SE: standard error 
The result of this research was in agreement to the report of Crouse and Dikeman (1976), Johnson and Davis (1983), and Priyanto et al. (1997) in which the carcass weight was indicator for predicting weight of total meat and fat. The same statement also reported by Abraham et al. (1968); Epley et al.(1970); Abraham et al. (1980); Miller et al. (1988) and Reiling et al. (1992).

The second alternative should be concerned as indicator was the fat thickness on the $12^{\text {th }}$ rib resulting from highly significant correlation $(\mathrm{P}<0.01)$ with content of meat and fat (accuracy level of $\mathrm{R}=46.4 \%$ and $\mathrm{SE}=5.02$ for meat, $\mathrm{R}=42.6 \%$ and $\mathrm{SE}=4.27$ for fat). This research was in agreement to the research of Priyanto (1993) and Taylor et al. (1996) in which fat thickness on the 12th rib as an alternative indicator, excluding thick of sub-cutan fat rump P8.

An indicator is called accurate when it shows high coefficient and small error standard in predicting a dependent variable. This research created the best simple linear regression:

$$
\begin{aligned}
\text { Meat }(\mathrm{kg})= & 10.64 * *+0.49 \mathrm{WC}^{* *} \\
& \mathrm{R}=72.8 \% \quad \mathrm{SE}=3.58 \\
\text { Fat }(\mathrm{kg})= & -21.7 * *+0.36 \mathrm{WC}^{* *} \\
& \mathrm{R}=58.2 \% \quad \mathrm{SE}=3.65
\end{aligned}
$$

The equation of simple linear regression involving TLR12 as independent variable was:

$$
\begin{aligned}
\text { Meat }(\mathrm{kg})= & 53.69 * *+9.47 \mathrm{FT} 12 * * \\
& \mathrm{R}=46.4 \% \quad \mathrm{SE}=5.02 \\
\text { Fat }(\mathrm{kg}) \quad & 8.97 * *+7.46 \mathrm{FT} 12 * * \\
& \mathrm{R}=42.6 \% \quad \mathrm{SE}=4.27
\end{aligned}
$$

Analysis of multiple regression showed that combination of weight of a half cold carcass with fat percentage kidney, pelvic, heart indicated highly significant correlation $(\mathrm{P}<0.01)$ and was able to increase accurate prediction of meat yield. The obtained accuracy was $\mathrm{R}^{2}=75.1 \%$ and $\mathrm{SE}=3.43$. There was no significant correlation $(\mathrm{P}>0.05)$ for fat.

This results showed that weight of a half cold carcass and fat percentage of kidney, pelvic, and heart could be combined for predicting weight of meat. The obtained multiple regression for this combination was:

$$
\begin{aligned}
& \text { Meat }(\mathrm{kg})= 7.99+0.58 \mathrm{WC}^{* *}-4.41 \mathrm{KPH}^{* *} \\
& \mathrm{R}^{2}=75.1 \quad \mathrm{SE}=3.43
\end{aligned}
$$

The important thing to be concerned in using the linear regression or multiple regression was avoiding bias (under estimated or over estimated). Therefore, it is beneficial to get information of cattle with its feed background. The use of the regression model will be more accurate when applied on the Crossbred Brahman Cattle (CBC) which is come from fattening with grain feed. The bias in implementing the regression model on different feed background has been proven by Priyanto (1993).

\section{CONCLUSION}

The use of weight of a half cold carcass as single indicator is more possible for predicting total weight of meat and fat carcass components with better accuracy level. The regression model was:

$$
\begin{aligned}
& \text { Meat }(\mathrm{kg})=10.64+0.49 \mathrm{WC}^{* *} \\
& \text { Fat }(\mathrm{kg})=-21.7+0.36 \mathrm{WC}^{* *}
\end{aligned}
$$

Analysis of multiple regression of combination among weight of a half cold carcass with fat percentage of kidney, pelvic, and heart caused the better accuracy as showed by equation: Meat $(\mathrm{kg})=7.99+0.58 \mathrm{WC}^{* *}-4.41 \mathrm{KPH}^{* *}$

\section{ACKNOWLEDGEMENTS}

This work was financed by BPPS Dikti Department of National Education RI. The authors would like to acknowledge the generous assistance of the abattoir staff and of the PT. Celmor Perdana Indonesia and Laboratory of Large Ruminant, Faculty of Animal Husbandry, IPB in Bogor for permission support.

\section{REFERENCES}

Abraham, H.C., Carpenter, Z.L., King, G.T. and Butler, O.D. 1968. Relationship of carcass weight, conformation and carcass measurements and their use in predicting beef carcass cutability. J. Anim. Sci. 27:604-610.

Abraham, H.C., Murphey, C.E., Cross, H.R., Smith, G.C. and Frank, W.J.Jr. 1980. Factor affecting beef carcass cutability: An evaluation of the U.S.D.A. yield grade for beef. J. Anim. Sci. 50:841-851.

Ball, B. and Johnson, E.R., 1989. The influence of breed and sex on saleable beef yield. Aust. J. Exp. Agric. 29:483-487.

Brungardt, V.H. and Bray, R.W. 1963. Estimated of retail yield of the four major cuts in the beef carcass. J. Anim. Sci. 22:177-182.

Butterfield, R.M., 1965. The relationship of carcass measurements and dissection data to beef carcass composition. Res Vet. Sci. 6:24-32. 
Charles, D.D. 1974. A method of estimating carcase component in cattle. Res. Vet. Sci. 16:89-94.

Crouse, J.D. and M.E. Dikeman. 1976. Determinates of retail products of carcass beef. J. Anim. Sci. 42:584.

Epley, R.J., H.B. Hedrick, W.C. Stringer and D.P. Hutcheson. 1970. prediction of weight percent retail cuts of beef using five carcass measurements. J. Anim. Sci. 30:872.

Gomez, K.A. and A.A. Gomez.1984. Statistical Procedures for Agricultural Research. $2^{\text {nd }}$ Edition. John Wiley \& Sons, Inc., Singapore.

Hopkins, D.L. Brooks, A.A. and Johnston, A.R. 1993. Proocedings Australian Meat industry Research Conference, Gold Coast, Session pp. 7-9.

Johnson, E.R.,1987. Comparison of twelfth rib and rump fat thickness measurement for predicting commercial beef yield in local market carcasses. Aust. J. Exp. Agric. 27:613-617.

Johnson, E.R. and Ball , B., 1988. An evaluation of rump P8 and twelfth rib fat thickness measuring sites for estimating saleable beef yield in export and local carcasses. In: Proceeding of the $34^{\text {th }}$ International Congress of Meat Science and Technology, pp. 71-73, Brisbane.

Johnson, E.R. and C.B. Davies. 1983. A caliper for determining carcass composition in live cattle and skin on carcasses. Aust. J. Agric. Res. 34:825-832.

Johnson, E.R. and Vidyadaran, M.K., 1981. An evaluation of different sites for measuring fat thickness in the beef carcass to determinate carcass fatness. Aust. J. Agric. Res. 32:999-1007.
Meehan, D.P. and Taylor, D.G., 1988. A comparison of positions for fat thickness measurements on beef carcasses. Proc. Aust. Soc. Anim. Prod. 17:440.

Miller, M.F., H.R. Cross, J.F. Baker and F.M. Byers. 1988. Evaluation of live and carcass techniques for predicting beef carcass composition. Meat Sci. 23:111.

Murphey, C.E., Hallet, D.K., Tyler, W.E., and Pierce, J.C. Jr., 1960. Estimating yields of retail cuts from beef carcasses. J. Anim. Sci. 19:1240 (Abstr.)

Priyanto, R., 1993. A study of the growth and distribution of beef carcass tissues including their prediction, optimum beef productivity and marketing. $\mathrm{PhD}$ Thesis, The University of Quensland.

Priyanto, R., E.R. Johnson and D.G. Taylor. 1997. Prediction of carcass composition in heavyweight grass-fed and grain-fed beef cattle. Anim. Prod. 57:65-72

Ramsay, C.B., Cole, J.W. and Hobbs, C.S., 1962. Relation of beef carcass grades, proposed yield grades and fat thickness to separable lean, fat and bone. J. Anim. Sci. 21:193195.

Reiling, B.A., G.H. Rouse and D.A. Duello. 1992. Predicting percentage of retail yield from carcass measurements, the yield grading equation and closely trimmed, boxed beef weight. J. Anim. Sci.70:2151-2158.

Taylor, D.G., Johnson, E.R. and Priyanto, R., 1996. The accuracy of rump P8 fat thickness and twelth rib fat thickness in predicting beef carcass fat content in three breed types. In: Proceedings of the Australian Society of Animal Production. The University of Quensland, Brisbane. P. 193-195. 